\title{
DAMPAK PERUBAHAN PENGGUNAAN LAHAN TERHADAP PERTUMBUHAN PRODUKSI PERTANIAN DI KABUPATEN KARANGANYAR TAHUN 2015-2019
}

\author{
Elvina Mukti Satiti, Khamsa'atun Salamah, Laila Fitri Mayrosidah, Dedi Yulianto, \\ M Faris Abdussalam, Chika Ayuko \\ Universitas Muhammadiyah Surakarta, Pabelan, Kartasura
}

\begin{abstract}
Abstrak: Terbatasnya ketersediaan lahan dan banyaknya tingkat kebutuhan terhadap lahan menyebabkan permasalahan perebutan penggunaan lahan dengan nilai keuntungan yang tinggi dan ekonomis dari penggunaan tanah. Penelitian ini bertujuan untuk mengetahui perubahan luas penggunaan lahan, perubahan alih funsi lahan, dan dampak penggunaan lahan terhadap produksi pertanian di Kabupaten Karanganyar. Dalam menganalisis data menggunakan data sekunder yang diperoleh dari BPS, departemen, dan lembaga pendidikan. Data dianalisis secara diskribtif. Hasil yang diperoleh dalam penelitian dapat membandingkan dan menganalisis perubahan hasil produksi dan luas lahan dari tahun ke tahun. Kabupaten Karanganyar memiliki lahan terluas berada pada tahun 2015 yang sampai pada angka 153.665 Ha, sedangkan pada tahun 2019 luas lahan mencapai 1.408.811 Ha. Hasil produksi pertanian tahun 2014 menurut jumlah dari hasil produksi terbanyak per kecamatan di Kabupaten Karanganyar mencapai 357.441,42 ton dan 2019 hasil produksi mencapai 1.579.658,72 Ton.
\end{abstract}

Kata kunci : perubahan penggunaan lahan, produksi pertanian

Abstract: The limited availability of land and the many levels of demand for land causes the problem of land use struggle with high profit and economic value from land use. This study aims to determine changes in land use area, changes in land function conversion, and the impact of land use on agricultural production in Karanganyar Regency. In analyzing data using secondary data obtained from BPS, departments, and educational institutions. Data were analyzed descriptively. The results obtained in the study can compare and analyze changes in production yields and land area from year to year. Karanganyar Regency has the largest land area in 2015 which reached 153,665 $\mathrm{Ha}$, while in 2019 the land area reached 1,408,811 $\mathrm{Ha}$. The results of agricultural production in 2014 according to the highest amount of production per sub-district in Karanganyar Regency reached 357,441.42 tons and in 2019 the production reached 1,579,658.72 tons.

Key words: land use change, agricultural production

\section{A. PENDAhuluan}

Lahan merupakan tempat yang dapat digunakan untuk kepentingan manusia yang mencakup sejumlah sumberdaya alam dan memiliki karakteristik yaitu iklim, topografi, hidrografi, hidrologi, biologi, tanah dan geologi. Segala kegiatan yang dilakukan manusia yang berkaitan dengan lahan dan sumberdaya alamnya disebut penggunaan lahan. Lahan memiliki peran penting dalam tatanan kehidupan manusia, karena manusia hidup diatas lahan dan seluruh kebutuannya memanfaatkan lahan. Penggunaan lahan di desa untuk memenuhi kebutuhan 
perekonomiannya biasanya melalui pertanian, jika tidak ada lahan, pertanian tidak bisa dilakukan dan kebutuhan perekonomian tidak dapat terpenuhi (Rindyantika, 2019). Terbatasnya ketersediaan lahan dan banyaknya tingkat kebutuhan terhadap lahan menyebabkan permasalahan perebutan penggunaan lahan dengan nilai keuntungan yang tinggi dan ekonomis dari penggunaan tanah yang akan berdampak buruk bagi lahan yang digunakan (Ernawati, 2008). Permasalahan lain yang menyebabkan perubahan lahan adalah perpindahan penduduk yang biasanya dilakukan dari desa ke kota dengan tujuan untuk mendapatkan sarana prasarana untuk kebutuhan hidup.

\section{Kabupaten}

Karanganyar digunakan sebagai lahan pertanian. Lahan pertanian ada dua jenis, yaitu lahan pertanian kering dan lahan pertanian basah. Di Kabupaten Karanganyar lahan basah memiliki luas 23.092 Ha pada tahun 2017, sedangkan lahan kering merupakan lahan tegalan atau kebun yang memiliki luas $14.530 \mathrm{Ha}$ pada tahun 2017 (Karanganyar, 2018). Lahan pertanian ini menjadi sumber perekonomian masyarakat di daerah penelitian karena sebagian besar penduduknya bekerja sebagai petani dan juga menjadi tumpuan masyarakat untuk memenuhi kebutuhan pangan. Kabupaten Karanganyar pada periode tahun 1998 sampai tahun 2010 mengalami alih fungsi lahan pertanian ke non pertanian di beberapa kecamatan yang meliputi Kecamatan Colomadu, Kecamatan Kebakkeramat dan Kecamatan Gondangrejo berturut-turut sebesar $231.830 \mathrm{Ha}, 198.310 \mathrm{Ha}$, dan 171.392 Ha (Prasetyo, 2012).

Tujuan dalam penelitian ini adalah untuk mengetahui perubahan luas penggunaan lahan di Kabupaten Karanganyar, perubahan alih funsi lahan yang terjadi di Kabupaten Karanganyar, serta mengetahui dampak penggunaan lahan terhadap produksi pertanian di Kabupaten Karanganyar.

\section{B. METODE}

Lokasi pengambilan sampel berada di Kabupaten Karaganyar, Jawa Tengah. Pengambilan sampel dilakukan pada titik lokasi tersebut. Dilanjutkan dengan pengolahan data atau analisis data yang dilaksanakan secara kuantitatif deskriptif.

Alat yang diperlukan pada penelitian ini untuk mengolah data yaitu laptop dan perangkat lunaknya Microsoft Excel. Data yang digunakan adalah data sekunder yang didapatkan dari berbagai sumber seperti BPS, departemen atau lembaga pendidikan.

Pengambilan data dengan menggunakan penelitian deskriptif bertujuan untuk mendeskripsikan, mencatat, analisis dan 
menginterprestasikan kondisi-kondisi yang sekarang terjadi. Data sekunder yang digunakan adalah data statistik Kabupaten Karanganyar tahun 20142017. Data ini mengenai jumlah dalam angka pembangunan manusia dan pertumbuhan produksi sayuran musiman.

Teknik pengumpulan data menggunakan data set statistik dan observasi.
Data yang diperoleh dianlisis secara deskriptif menggunakan Microsoft Excel dan disajikan berupa tabel.

\section{HASIL DAN PEMBAHASAN}

Data variabel lahan pada penelitian ini meliputi lahan sawah dan lahan kering.

Tabel. Jumlah Lahan Pertanian Terluas Tahun 2015 dan 2019.

\begin{tabular}{|c|c|c|c|}
\hline No. & $\begin{array}{l}\text { Nama } \\
\text { Tanaman }\end{array}$ & $\begin{array}{c}\text { Lahan Terluas Tahun } \\
2015\end{array}$ & Lahan Terluas Tahun 2019 \\
\hline 1. & Bawang Merah & Tawangmangu $(35 \mathrm{Ha})$ & Tawangmangu (128 Ha) \\
\hline 2. & Bawang Putih & Tawangmangu (114 Ha) & Tawangmangu (108 Ha) \\
\hline 3. & Kentang & Tawangmangu (114 Ha) & - \\
\hline 4. & Kubis & Tawangmangu (148 Ha) & Tawangmangu (76 Ha) \\
\hline 5. & Sawi & Matesih $(357 \mathrm{Ha})$ & Tawangmangu $(287 \mathrm{Ha})$ \\
\hline 6. & Cabai & Kerjo $(2.777 \mathrm{Ha})$ & Ngargoyoso dan Jenawi (123 Ha) \\
\hline 7. & Tomat & Ngargoyoso (49 Ha) & Ngargoyoso $(50 \mathrm{Ha})$ \\
\hline 8. & Terong & Jatiyoso $(17 \mathrm{Ha})$ & Jumantono (32 Ha) \\
\hline 9. & Buncis & Tawangmangu (34 Ha) & Jatiyoso $(59 \mathrm{Ha})$ \\
\hline 10. & Petai & Jumantono (74.836 Ha) & Jenawi (12.430 Ha) \\
\hline 11. & Jengkol & Jumantono $(3.844 \mathrm{Ha})$ & Ngargoyoso (1.800 Ha) \\
\hline 12. & Wortel & Ngargoyoso (438 Ha) & Tawangmangu (523 Ha) \\
\hline 13. & Mlinjo & Tasikmadu (15.000 Ha) & Jumantono (4.630 Ha) \\
\hline 14. & Kacang Panjang & Kerjo $(28 \mathrm{Ha})$ & Jumantono $(41 \mathrm{Ha})$ \\
\hline 15. & Cengkeh & Tawangmangu $(207,20 \mathrm{Ha})$ & Jatiyoso $(190,96 \mathrm{Ha})$ \\
\hline 16. & Kelapa Dalam & Mojogedang (368,94 Ha) & Jenawi $(351,34 \mathrm{Ha})$ \\
\hline 17. & Mete & Jumantono $(54,45 \mathrm{Ha})$ & Jumantono $(51,05 \mathrm{Ha})$ \\
\hline 18. & Kopi Arabica & Karangpandan $(19,55 \mathrm{Ha})$ & Ngargoyoso $(14,85 \mathrm{Ha})$ \\
\hline 19. & Kopi Robusta & Jatiyoso $(4.600 \mathrm{Ha})$ & Ngargoyoso $(7,65 \mathrm{Ha})$ \\
\hline 20. & Tebu & Karanganyar $(484,51 \mathrm{Ha})$ & Karanganyar $(448,36 \mathrm{Ha})$ \\
\hline 22. & Lada & Karanganyar $(6,96 \mathrm{Ha})$ & Karanganyar $(5,76 \mathrm{Ha})$ \\
\hline 23. & Tembakau & Jatiyoso $(45,2 \mathrm{Ha})$ & Colomadu $(96,2 \mathrm{Ha})$ \\
\hline 24. & Vanili & - & - \\
\hline 25. & Kapuk & Gondangrejo $(1,67 \mathrm{Ha})$ & Colomadu $(1,52 \mathrm{Ha})$ \\
\hline 26. & Jahe & Jatiyoso (12.103 Ha) & Ngargoyoso (1.140.000 Ha) \\
\hline 27. & Kencur & Jatipuro $(7.032 \mathrm{Ha})$ & Jatipuro $(30.000 \mathrm{Ha})$ \\
\hline 28. & Kunir & Jatiyoso (19.360 Ha) & Jumapolo (209.000 Ha) \\
\hline 29. & Kelapa & - & - \\
\hline 30. & Kelapa Hibrida & - & - \\
\hline 31. & Padi & Jenawi (7.249 Ha) & Kebakkramat (5.909 Ha) \\
\hline 32. & Jagung & Jatiyoso (1.084 Ha) & Jatiyoso $(952 \mathrm{Ha})$ \\
\hline 33. & Ubi Kayu & Jumantono (808 Ha) & Jatiyoso $(610 \mathrm{Ha})$ \\
\hline 34. & Ubi Jalar & Matesih $(277 \mathrm{Ha})$ & Ngargoyoso (150 Ha) \\
\hline 35. & Kedelai & Kerjo (116 Ha) & Mojogedang (243 Ha) \\
\hline 36. & Kacang Tanah & Jumantono $(2.057 \mathrm{Ha})$ & Jumantono (484 Ha) \\
\hline & Jumlah & 153.665 Ha & 1.408.811 Ha \\
\hline
\end{tabular}


Tabel di atas menunjukkan jumlah lahan pertanian jenis tanaman sayuran terluas pasa tahun 2015 dan 2019 di Kabupaten Karanganyar. Dari data tabel diatas kita dapat mengetahui perbedaan jumlah keseluruhan lahan terluas pada tahun 2015 luasnya mencapai 153.665 Ha sedangkan tahun 2019 mencapai 1.408.811 Ha. Terdapat kenaikan jumlah luas lahan yang cukup banyak dari rentang waktu selama 4 tahun, hal ini menunjukkan bahwa luas lahan yang digunakan untuk pertanian jenis tanaman bertambah luasnya dari tahun ketahun di Kabupaten Karanganyar.

Hasil produksi pertanian tahun 2014 menurut jumlah dari hasil produksi terbanyak per kecamatan di Kabupaten Karanganyar mencapai 357.441,42 Ton dan 2019 hasil produksi mencapai 1.579.658,72 Ton, dari data Badan Pusat Statistik tersebut dapat dilihat peningkatan yang cukup tinggi dikarenakan luas lahan yang bertambah juga mempengaruhi hasil produksi pertaniannya.

Penelitian ini kami bandingkan dengan penelitian relevan yang telah dilakukan sebelumnya oleh Catur Setyo Wibowo dengan judul "Dampak Pengalihan Fungsi Lahan Sawah Pada Produksi Padi Sampai Tahun 2018 Dan Implikasinya Terhadap Ketahanan
Pangan Wilayah (Studi Di Kecamatan Jaten Kabupaten Karanganyar Provinsi Jawa Tengah)" dengan metode kuantitatif bersumber data primer dan sekunder. Penelitian ini bertujuan untuk mengetahui luas lahan sawah yang telah dialih fungsikan kegunaannya di Kecamatan Jaten pada tahun 2018, mengetahui faktor penyebab pengalihan lahan, dan mengetahui dampak pengalihan lahan sawah terhadap produksi padi dalam rangka ketahanan pangan di Kecamatan Jaten sampai tahun 2018. Hasil yang didapatkan pada penelitian tersebut menunjukkan bahwa di Kecamatan Jaten pengalihan fungsi lahan sawah mengalami peningkatan yang berdampak pada jumlah produksi padi secara total, dengan penurunan sebesar $6.309,8$ ton sampai pada tahun 2018.

\section{KESIMPULAN}

Berdasarkan hasil penelitian dan pembahasan, dapat disimpulkan melalui analisis data lahan pertanian dan produksi pertanian menunjukan rata-rata produksi pertanian di Kabupaten Karanganyar mengalami peningkatan seiring dengan jumlah luas lahan pertanian yang juga mengalami peningkatan. Tanaman yang mengalami peningkatan diantaranya Bawang merah, Kedelai, Kunir, Kencur, Jahe, Tembakau, 
Tomat, Wortel, Buncis, dan Kacang Panjang. Luas lahan yang mengalami peningkatan yang pesat dari tahun 2015 ke 2019 adalah lahan tanaman Jahe di Kecamatan Ngargoyoso yang mencapai 1.140.000 Ha. Meski mengalami peningkatan baik luas lahan dan jumlah produksi pertanian, akan tetapi secara umum jenis komoditas bahan pangan mengalami penurunan luas lahan pertanian. Beberapa yang mengalami penurunan diantaranya Sawi, Bawang Putih, Kentang, Kubis, Kacang Tanah, Jagung, Ubi Jalar, Padi, Lada, tebu, Mete, Kelapa Dalam, Cengkeh, Mlinjo, Petai, Cabai, Kopi Arabica, Kopi Robusta. Pada rentang waktu tahun 2015 hingga 2019 lahan yang mengalami penurunan jumlah luasnya yang paling banyak yaitu pada lahan tanaman Petai di Kecamatan Jumantono yang pada tahun 2015 mencapai luas 74.836 Ha dan pada tahun 2019 mengalami penurunan sehingga pada saat tahun 2019 tanaman Petai yang terluas ada di Kecamatan Jenawi.

\footnotetext{
Berdasarkan kesimpulan yang telah dipaparkan maka saran untuk pemerintah Kabupaten Karanganyar yakni: (1) pemerintah memperhatikan perubahan lahan pertanian yang terjadi di beberapa kecamatan yang mengalami penurunan luas lahan pertanian secara signifikan maupun relatif sedikit. (2)
}

pengembangan potensi dan menjaga penghasilan produksi pertanian terutama bahan pangan. Potensi setiap wilayah di Kabupaten Karanganyar merupakan modal besar dalam pemenuhan kebutuhan pangan.

\section{DAFTAR PUSTAKA}

Ernawati, N. (2008). Analisis Perubahan Penggunaan Lahan Di Kecamatan Kebakkeramat Kabupaten Karanganyar tahun 1996 dan 2005. Skripsi I, 3.

Juhadi. (2007). Pola-pola Pemanfaatan Lahan Dan Degradasi Lingkungan Pada Kawasan Perbukitan . Jurnal Geografi Volume 4, 1.

Karanganyar, B. (2017, 10 26). Kabupaten Karanganyar Dalam Angka. Retrieved 04 2020, 20, from karanganyarkab.bps.go.id: https://karanganyarkab.bps.go.id/ publication/2017/10/26/615aa4a3 7e1af5c48f494125/kabupatenkaranganyar-dalam-angka2016.html

Karanganyar, B. (2018, 09 26). Karanganyar Dalam Angka. Retrieved 04 20, 2020, from karanganyarkab.bps.go.id: https://karanganyarkab.bps.go.id/ publication/2018/08/16/50483865 81b2868436d40a23/kabupatenkaranganyar-dalam-angka2018.html 
Prasetyo, A. (2012). Faktor-faktor Yang Mempengaruhi Alih Fungsi Lahan Pertanian Ke Sektor Non Pertanian Di Kabupaten Karanganyar. Skripsi, 3.

Rindyantika, P. (2019). Analisis Spasial Perubahan Penggunaan Lahan Di Kecamatan Jaten Kabupaten Karanganyar Tahun 2008 Dan 2018. Skripsi I , 2.
Wibowo, C. S. (2015). Dampang Pengalihan Fungsi Lahan Sawah Pada Produksi Padi Sampai Tahun 2018 dan Implikasinya Terhadap Ketahanan Pangan Wilayah. Jurnal Ketahanan Nasional Vol. 21 No. 2, 107117. 